\title{
Percentage of Lateral Pterygoid Muscle Inserted in the Disc of Human Temporomandibular Joint
}

\author{
Porcentaje del Músculo Pterigoideo Lateral Inserto en el \\ Disco de la Articulación Temporomandibular Humana
}

"Jorge Tapia Contreras; ** Mario Cantín; *** Daniela Zavando \& *Iván Suazo Galdames

TAPIA, C. J.; CANTín, M.; ZAVANDO, D. \& SUAZO, G. I. Percentage of lateral pterygoid muscle inserted in the human temporomandibular joint disc. Int. J. Morphol., 29(3):965-970, 2011.

SUMARY: Insertion of the upper head of the lateral pterygoid (UHLP) in the temporomandibular joint disc (TMJ) has been linked to anterior displacement of the disc and temporomandibular disfunction. The aim of this study was to determine in human adults, the percentage of muscle fiber in the upper head of the lateral pterygoid muscle inserted in the articular disc. A systematic review of the literature was designed beginning with articles published in Medline, Lilacs and Scielo data bases between the years 1990 and 2010. Key words "Lateral Pterygoid Muscle" and Pterygoid Lateral Muscle" were used, and the term MeSH "Pterygoid Muscle" with Boolean OR "Lateral Ptrerygoid Muscle" AND "Insertion" and the free terms "Pterygoid Lateral Muscle Disc Articular" and "Pterygoid lateral Muscle Meniscus". Of the 156 articles obtained and analyzed, 18 articles meeting eligibility criteria were selected. Based on those articles the percentage of insertion of the CSPL in the TMJ disc was evaluated, each one was subsequently assigned a level of evidence according to OCEBM Oxford Centre Evidence Based Medicine. Only four articles answered the research inquiry, three studies were histological and one used imaging techniques with cross section slices with an adequate evidence level (1B). However, results differed with insertion percentages from $2 \%$ to $69.8 \%$ being reported in the superior head of the lateral pterygoid muscle in the articular disc.

KEY WORDS: Lateral pterygoid muscle; Articular disc; Morphology based on evidence; Systematic review.

\section{INTRODUCTION}

The lateral pterygoid muscle is a short and thickset muscle of multi penniform aspect located in the infra-temporal region. The muscle originates antero-medially from two fascicles: The upper head originates on the infratemporal surface and infratemporal crest of the greater wing of the sphenoid bone, and the lower/inferior head on the lateral surface of the lateral pterygoid plate originating three quarters or two lower thirds of the lateral aspect of the lateral lamina in the pterygoid process of the palatine bone, which origin springs from short tendinous and fleshy fibers. (Latarjet \& Ruiz-Liard, 2004: Moore \& Dalley, 2007; Rouviere \& Delmas, 2002; Testut \& Latarjet, 1972, Williams \& Warwick 1985).

At the double origin converging muscular fibers extend posterior and laterally (Palastanga et al., 2000), the upper head inserts mainly in the joint disk and capsule of the temporomandibular joint (TMJ); the lower head inserts mainly in the pterygoid depression of the antero-medial surface of the condylar process of the mandible (Moore \& Dalley; Williams \& Warwick).

In its function a single lateral pterygoid muscle contraction causes lateral movement in which one of the heads of the jaw pivots while the other moves anteriorly (Rouviere \& Delmas). The contraction of both muscles determines an anterior projection or protrusion of the mandible (Testut \& Latarjet). Further during the process of opening of the mouth, contraction of the lateral pterygoid muscles mandibular neck and joint disc are displaced anteriorly (Snell, 2002).

Insertion of the lateral pterygoid muscle in the joint disc of the TMJ is fundamental for mandibular dynamic and has been studied by a number of authors Naidoo (1996) no-

* Universidad de Talca, Chile

** Facultad de Medicina, Universidad de La Frontera, Chile.

**** Universidad Autónoma de Chile, Sede Talca, Chile. 
tes the existence of a variable insertion of the upper head of the pterygoid muscle lateral to the TMJ disc. Bittar el al., (1994) indicate that $31 \%$ of muscle fibers insert in the articular disc. According to Naohara (1989) insertion is the equivalent of $30 \%$ of the muscular fibers; similar information reported by Naidoo \& Juniper (1997), who reported that $29.5 \%$ of fibers insert in the disc. Zhang et al., (1998) indicate that only $10 \%$ of fibers insert in the disc. For Filho et al., (2010a) the percentage of the upper head of the lateral pterygoid inserts in the disc and varies in 68 to $74 \%$. Classical anatomic literature does not clearly describe upper lateral pterygoid fibers inserted in the disc (Latarjet \& Ruiz-Liard, Moore \& Dalley, Rouvière \& Delmas, Williams \& Warwick; Testut \& Latarjet).

Considering the lack of consensus in the literature and the importance evaluation has on the insertion percentage of the lateral pterygoid upper head on the TMJ disc, and risk factor in the anterior disc displacement and development of joint pathology (Filho et al., 2010a). For Suazo \& Manterola (2010) it is possible to evaluate a number of morphological topics through systematic review of the literature. The aim of this study is to determine the percentage of muscular fibers of the upper head of the lateral pterygoid muscle inserting in the joint disc in human adults commencing with a study of articles published in the data bases of Medline, Lilacs and Scielo between 1990 and 2010.

\section{MATERIAL AND METHOD}

An observational and analytical study was designed based on systematic review of the literature.

Search Strategy. Electronic data bases as Medline, LILACS and Scielo were used only for the 1990-2010 period. Key words for the search in Scielo were: "Musculo Pterigoideo Lateral", "Musculo Pterigoideo" , "Lateral Pterygoid Muscle", "Pterygoid Muscle", in LILACS and BBO: "Musculo Pterigoideo Lateral" and "Lateral Pterygoid Muscle". In Medline the term MeSH was used: "Pterygoid Muscle" with the boolean: OR Lateral Pterygoid Muscle AND insertion, in addition to the free terms: "Pterygoid Lateral Muscle Disc Articular" and "Pterygoid Lateral Muscle Meniscus". Tripdatabase and Cochrane Library: "Lateral Pterygoid Muscle". Gray literature concerning the lateral pterygoid muscle in human anatomy literature and text summaries of anatomy congresses, were reviewed extensively.

Population: Biomedical articles identified by defined search strategy of Medline, LILACS and Scielo data bases only considered primary articles which objective was to determine the disc insertion of the upper head of the lateral pterygoid muscle, carried out in humans over 18 years of age without sex distinction, published in English, French, Portuguese and Spanish between 1990 and May, 2010. Articles that included patients with skeletal muscle disease, malformations or TMJ surgeries, were not included.

Analysis Procedure. Once articles were identified in the data bases, complete texts were read followed by analysis carried out independently by two researchers, in the event of discrepancies the opinion of the Centro Colaborador Cochrane UFRO of the Red Cochrane Iberoamericana was requested, and in case of continued disagreement a decision was made by consensus. The analysis consisted in:

1. Each article was assigned a level of evidence according to the Oxford Centre Evidence Based Medicine (OCEBM) classification, updated in 2009 (Manterola \& Zavando, 2009).

2. The studieswere arranged according to the study's approach of the insertion, directly when carried out in cadavers, and indirectly when carried out with imaging methods.

Strategy of the search used is detailed in Figure 1.

\section{RESULTS}

Of the 18 articles selected, 15 used cadaveric material of which 7 realized macroscopic analysis, 2 realized histological analysis and in 6 articles macroscopic and histological analysis were combined. In the 3 remaining articles analysis was carried out based on magnetic resonance imaging.

Sites for lateral pterygoid muscle insertion in the articular disc. Coskun et al., 2009 \& Matsunaga et al., 2009 contributed non-specific results, these authors noted that only a few fibers of the lateral pterygoid muscle insert in the articular disc, Mazza et al., 2009 \& Naidoo indicated that some fibers of the upper head of the lateral pterygoid muscle would insert in the articular disc and the condylar process, while in other muscle bundles disc insertion waas exclusive. Ben Amor et al. (1998) determined the width of the lateral pterygoid upper head from $13.5 \pm 3.75 \mathrm{~mm}$ for men and $14.5 \pm 3.64 \mathrm{~mm}$ for women. Pompei et al., in 2009 while studying the presence of a third head of the lateral pterygoid muscle observed with imaging, a superoinferior insertion area in the disc of $4.14 \mathrm{~mm}$ in women and $4.67 \mathrm{~mm}$ in men. 


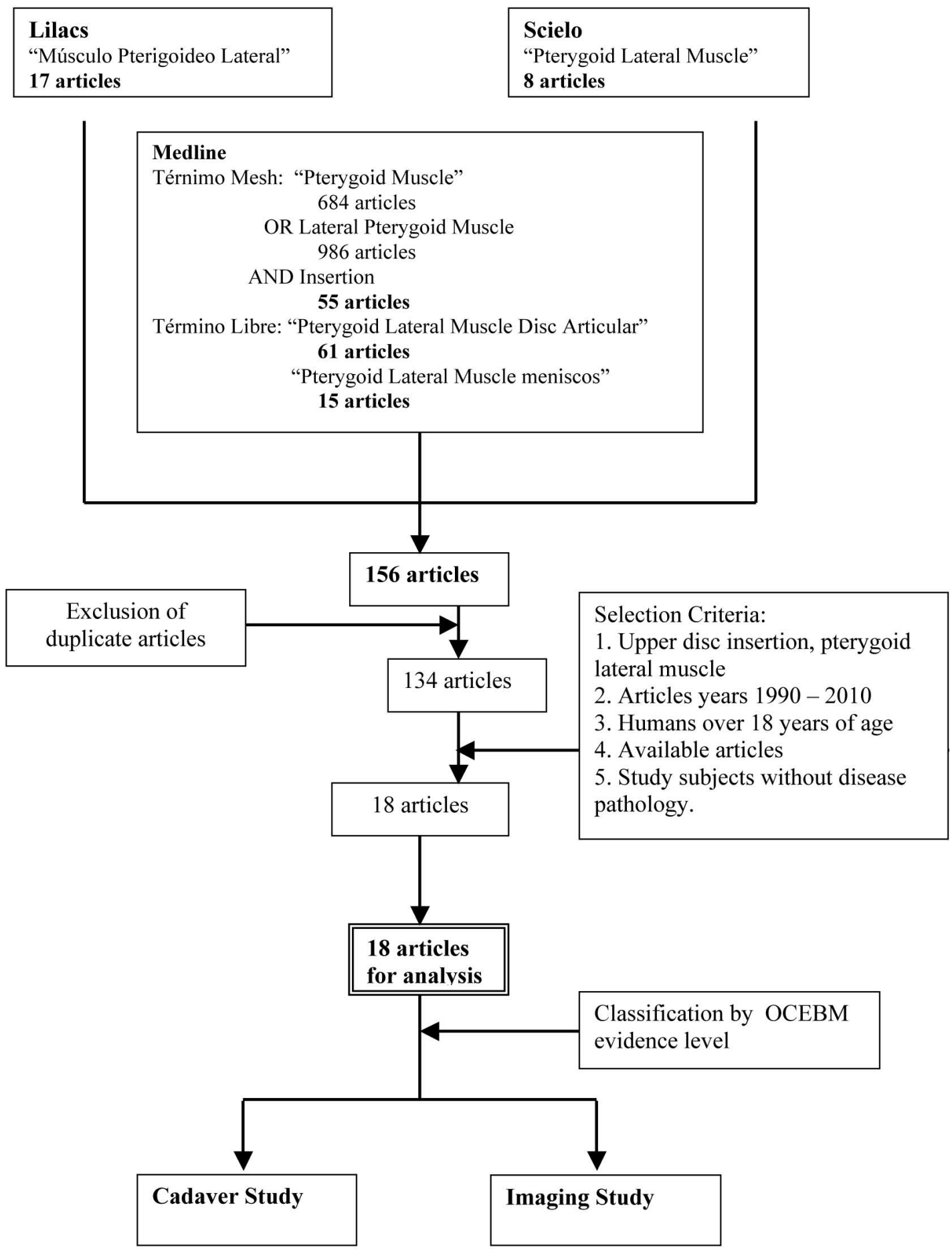

Fig. 1. Search strategy outline of articles to dteremine percentage of lateral pterygoid muscle disc insertion..

Certain research studies indicated more specifically that these fibers insert in the lower border of the articular disc (Matsunaga et al., Usui et al., 2008); another report indicates the presence of muscle bundles inserted only in the anteromedial border of the articular capsule in close contact with the disc (Minarelli \& Leberti, 1996). A considerable number of articles concur that insertion is generally located in the anteromedial area of the disc (Akita et al., 2000; Bade, 1999; Bravetti et al., 2004; Fujita et al., 2001; Wongwatana et al., 1994). 
Christo et al. (1995), reported a discrepancy in the diagnosis of disc insertion in macroscopic and microscopic observations of the same specimens. At a macroscopic level disc insertion of the lateral pterygoid muscle was observed, however, during observation of the same specimen at a microscopic level, it was confirmed that this occurs in the articular capsule only, without direct relation between muscle-disc as the disc is firmly attached to the articular capsule, giving the impression that the disc and muscle were solidly joined.

Fujita et al. \& Naidoo reported disc insertion of the lower head of the lateral pterygoid muscle, while Pompei et al., described a third head of the lateral pterygoid muscle with complete insertion in the disc with a prevalence of $22 \%$.

Disc insertion percentage of the lateral pterygoid muscle. Only 4 of the articles studied responded the research inquiry about the disc insertion percentage of the upper head of the lateral pterygoid muscle. During histological studies Bravetti et al., determined that the upper head of the muscle inserts through the tendinous leaf in the disc anterior border, such insertion constituting $2 \%$ of the total muscle; Naidoo \& Juniper reported that $29.5 \%$ of fibers of the upper head of the lateral pterygoid muscle insert in the medial third of the disc. Furthermore, Bittar et al., during a study of $20 \mathrm{TMJ}$ noted in 5 samples that fibers inserted directly in the disc and constituted $2.4 \%$ to $6.3 \%$ of the superoinferior length of the muscle, and lastly Filho et al., (2010a) determined through imaging that insertion percentage of the upper head of the lateral pterygoid muscle in the disc is $69.8-68.94 \%$, with highest values reported in this review.

Evidence levels of scientific articles analyzed. Analyzing all articles it was determined these are descriptive studies of transverse cuts (Manterola \& Suazo, 2010), which presented 1B level of evidence (Manterola \& Zavando).

\section{DISCUSSION}

The main objective of this systematic review was to review and carry out a qualitative analysis of current scientific literature available on Medline, Lilacs and Scielo in reference to disc insertion of lateral pterygoid muscle in the TMJ articular disc.

Literature analyzed did not adequately satisfy the research question relating to the percentage of lateral pterygoid muscle fibers that insert in the human temporomandibular joint disc. Most articles that studied disc insertion of the muscle did not report details with a qualitative approach, describing the general form of insertion in the disc area of insertion in the TMJ. The majority of the studies were of transverse sections, (a reduced number of cases), with recurrent lack of information regarding methodology used for sample selection and information access.

Only 4 articles responded the research inquiry, 3 were histological studies and one study through imaging; all with transverse sections with adequate evidence (1b). However results were dissimilar, reporting insertion percentages from $2 \%$ to $69.8 \%$ of the upper head of the lateral pterygoid in the articular disc.

It appears reasonable the morphology research inquiries are answered with descriptive studies and transverse section designs, an adequate number of cases, clearly described and reproducible methodology, to allow clinicians make decisions based on morphological evidence. A first step was developed by Becker et al., 2009a, denominated the beginning of morphology based on evidence (Suazo \& Manterola, 2009), nevertheless heterogeneity of studies and lack of tools that allow meta analyzing of the data obtained in morphological literature render practical use of this methodology more difficult (Becker et al., 2009b), comparison of studies and recommendations based on evidence.

TAPIA, C. J.; CANTÍN, L. M.; ZAVANDO, D. \& SUAZO, G. I. Porcentaje del músculo pterigoideo lateral inserto en el disco de la articulación temporomandibular humana. Int. J. Morphol., 29(3):965-970, 2011.

RESUMEN: La actividad de la inserción de la cabeza superior del pterigoideo lateral (CSPL) en el disco de la articulación temporomandibular (ATM) ha sido vinculada al desplazamiento anterior del disco y disfunción temporomandibular. El propósito de este estudio fue determinar el porcentaje de fibras musculares de la cabeza superior del músculo pterigoideo lateral que se insertan en el disco articular, en humanos adultos. Se diseñó una revisión sistemática de la literatura a partir de artículos primarios publicados en las bases de datos Medline, Lilacs y Scielo entre los años 1990 y 2010. Se utilizaron las palabras clave "Músculo Pterigoideo Lateral" y "Pterygoid Lateral Muscle", el Término MeSH: "Pterygoid Muscle" con los boleanos OR "Lateral Pterygoid Muscle" AND "Insertion" y los Términos Libres: "Pterygoid Lateral Muscle Disc Articular" y "Pterygoid lateral Muscle Meniscus". Se obtuvieron 156 artículos, los cuales fueron analizados y se seleccionaron 18 que cumplieron con los criterios de elegibilidad. En base a estos artículos se evaluó el porcentaje de inserción de la CSPL en el disco de la ATM, posteriormente a cada uno se les otorgó un nivel de evidencia de acuerdo a la clasificación de Oxford Centre Evidence Based Medicine (OCEBM). Solo 4 artículos res- 
pondieron a la pregunta de investigación, 3 estudios fueron histológicos y 1 imagenológico, todos con diseños de cortes transversales con buen nivel de evidencia (1b). Sin embargo los resultados fueron disímiles, reportándose porcentajes de inserción del 2 al 69,8\% de la cabeza superior del pterigoideo lateral en el disco articular.

PALABRAS CLAVE: Músculo pterigoideo lateral; Disco articular; Morfología basada en evidencia; Revisión sistemática.

\section{REFERENCIAS BIBLIOGRÁFICAS}

Akita, K.; Shimokawa, T. \& Sato, T. Positional relationships between the masticatory muscles and their innervating nerves with special reference to the lateral pterygoid and the midmedial and discotemporal muscle bundles of temporalis. J. Anat., 197:291-302, 2000.

Bade, $\mathrm{H}$. The function of the disco-muscular apparatus in the human temporomandibular joint. Ann. Anat., 181:657, 1999 .

Ben Amor, F.; Carpentier, P.; Foucart, J. M. \& Meunier, A. Anatomic and mechanical properties of the lateral disc attachment of the temporomandibular joint. J. Oral Maxillofac. Surg., 56:1164-7, 1998.

Becker, I.; Woodley, S. J. \& Baxter, G. D. Gross morphology of the vastus lateralis muscle: An anatomical review. Clin. Anat., 22:436-50, 2009a.

Becker, I.; Woodley, S. J. \& Baxter, G. D. Response to "The beginning of the evidence-based morphology". Clin. Anat., 22:854, 2009b.

Bittar, G. T.; Bibb, C. A. \& Pullinger, A. G. Histologic characteristics of the lateral pterygoid muscle insertion to the temporomandibular joint. J. Orofac. Pain, 8:2439, 1994.

Bravetti, P.; Membre, H.; El Haddioui, A.; Gérard, H.; Fyard, J. P.; Mahler, P. \& Gaudy, J. F. Histological study of the human temporo-mandibular joint and its surrounding muscles. Surg. Radiol. Anat., 26:371-8, 2004.

Coskun Akar, G.; Govsa, F. \& Ozgur, Z. Examination of the heads of the lateral pterygoid muscle on the temporomandibular joint. J. Craniofac. Surg., 20:21923, 2009.
Christo, J. E.; Bennett, S.; Wilkinson, T. M. \& Townsend, G. C. Discal attachments of the human temporomandibular joint. Aust. Dent. J., 50:152-60, 2005.

Filho, P. H.; Suazo, G. I. \& Guimaraes, A. S. Superior head of the lateral pterygoid muscle inserting in asymptomatic temporomandibular joints. Int. J. Odontostomat., 28(4):19-22, $2010 b$.

Filho, P. H.; Suazo, G. I.; Zavando, M. D. \& Guimaraes, A.S. Anterior disc displacement and the Superior head of Lateral pterygoid muscle. A Case-Control Study. Int. J. Morphol., 28(2):365-8, 2010a.

Fujita, S.; Iizuka, T. \& Dauber, W. Variation of heads of lateral pterygoid muscle and morphology of articular disc of human temporomandibular joint--anatomical and histological analysis. J. Oral Rehabil., 28:560-71, 2001.

Heylings, D. J.; Nielsen, I. L. \& McNeill, C. Lateral pterygoid muscle and the temporomandibular disc. $J$. Orofac. Pain, 9:9-16, 1995.

Latarjet, M. \& Ruiz-Liard, A. Anatomía Humana. $4^{\mathrm{a}}$ ed. Buenos Aires, Panamericana, 2004. p.1362.

Manterola, C. \& Zavando, D. Cómo interpretar los "Niveles de Evidencia" en los diferentes escenarios clínicos. Rev. Chil. Cir., 6:582-95, 2009.

Matsunaga, K.; Usui, A.; Yamaguchi, K. \& Akita, K. An anatomical study of the muscles that attach to the articular disc of the temporomandibular joint. Clin. Anat., 22:932-40, 2009.

Mazza, D.; Marini, M.; Impara, L.; Cassetta, M.; Scarpato, P.; Barchetti, F. \& Di Paolo, C. Anatomic examination of the upper head of the lateral pterygoid muscle using magnetic resonance imaging and clinical data. $J$. Craniofac. Surg., 20:1508-11, 2009.

Minarelli, A. \& Liberti, E. Relação entre o feixe superior do músculo pterigóideo lateral e o disco da ATM humana: estudo ao microscópio de luz. Rev. Odontol. Univ. São Paulo, 10:175-9, 1996

Moore, K. \& Dalley, A. Anatomía con Orientación Clínica. $5^{\mathrm{a}}$ ed. Buenos Aires, Panamericana, 2007. p.987.

Naidoo, L. C. Lateral pterygoid muscle and relationship to the meniscus of the temporomandibular joint. Oral Surg. Oral Med. Oral Pathol. Oral Radiol. Endod., 82:4-9, 1996. 
TAPIA, C. J.; CANTíN, L. M.; ZAVANDO, D. \& SUAZO, G. I. Percentage of lateral pterygoid muscle inserted in the human temporomandibular joint disc. Int. J. Morphol., 29(3):965-970, 2011.

Naidoo, L. C. \& Juniper, R. P. Morphometric analysis of the insertion of the upper head of the lateral pterygoid muscle. Oral Surg. Oral Med. Oral Pathol. Oral Radiol. Endod., 83:441-6, 1997.

Naohara, H. The macroscopic and microscopic study of the human lateral pterygoid muscle. Tsurumi Shigaku, 15:126, 1989.

Palastanga, N; Field, D. \& Soames, R. Anatomía y movimiento humano estructura y funcionamiento. $1^{\mathrm{a}} \mathrm{ed}$. Barcelona, Paidotribo, 2000. p. 506.

Rouvière, H. \& Delmas, A. Anatomía Humana descriptiva, topográfica y funcional. 10 a ed. Barcelona, Masson, 2002. p.140-1.

Snell, R. Anatomía Clínica para estudiantes de medicina. $6^{\mathrm{a}}$ ed. México D.F. McGraw-Hill Interamericana Editores, 2002. p.706.

Suazo, I. \& Manterola, C. The beginning of the evidencebased morphology. Clin. Anat., 22:783, 2009.

Suazo, G. I. \& Manterola, D. C. What is published in Human Morphology? Types of designs and Levels of evidence. Int. J. Morphol., 28(2):461-70, 2010.

Testut, L. \& Latarjet, A. Compendio de Anatomía Descriptiva. 22a ed. Barcelona, Salvat, 1972. p.155.

Usui, A.; Akita, K. \& Yamaguchi, K. An anatomic study of the divisions of the lateral pterygoid muscle based on the findings of the origins and insertions. Surg. Radiol. Anat., 30:327-33, 2008.

Williams, P. \& Warwick, R. Gray Anatomia. 36 a ed. Barcelona, Salvat, 1985. p.591.

Wongwatana, S.; Kronman, J. H.; Clark, R. E.; Kabani, S. \& Mehta, N. Anatomic basis for disk displacement in temporomandibular joint (TMJ) dysfunction. Am. J. Orthod. Dentofacial. Orthop., 105:257-64, 1994.

Zhang, L.; Sun, L. \& Ma, X. A macroscopic and microscopic study of the relationship between the superior lateral pterygoid muscle and the disc of the temporomandibular joint. Zhonghua Kou Qiang Yi Xue Za Zhi, 33:267-9, 1998.
Dirección para correspondencia:

Prof. Dr. Iván Suazo Galdames

Morfología

Avenida Lircay s/n oficina $N^{\circ} 104$

Universidad de Talca

CHILE

Phone: 56-71-201682

Email: isuazo@utalca.cl

Recibido : 22-05-2011

Aceptado: 22-06-2011 